\title{
Significance of isotopic and geochemical methods to determine the evolution of inland brackish and bitter water: an example from the Zuli river in the upper reaches of the Yellow River, China.
}

\author{
zihao liu ${ }^{1}$, Hongbing Tan ${ }^{1}$, and Mark Brusseau ${ }^{2}$ \\ ${ }^{1}$ Hohai University \\ ${ }^{2}$ The University of Arizona
}

July 1, 2020

\begin{abstract}
With the increasing demand for water resources, the utilization of marginal water resources of poor-quality has become a focus of attention. The brackish water developed in the Loess Plateau is not only salty but also famous for its "bitterness". In the present work, multi-isotope analysis ( $\mathrm{Sr}, \mathrm{B}$ ) was combined with geochemical analysis to gain insight into the hydrogeochemical evolution and formation mechanisms of brackish water. These results demonstrate that groundwater in the headwater is influenced by carbonate weathering. After the confluence of several tributaries in the headwater, the total dissolved solids (TDS) of water is significantly increased. The dissolution of evaporates is shown to be the main source of salinity in brackish water, which also greatly affects the Sr isotopic composition of water. This includes the dissolution of Mg-rich minerals, which is the main cause of the bitterness. Furthermore, the release of calcium from the dissolution of gypsum may induce calcite precipitation and incongruent dissolution of dolomite, which also contributes to the enrichment of magnesium. The highly fractionated boron isotopic values observed in the upstream groundwater were explained by boron interacting with clays, illustrating the important role played by the cationic exchange reaction. The inflow of brackish groundwater is the source of the observed quality of the river water. River water with relatively enriched 11B contents reflects the occurrence of evaporation along the flow path of the river. This process further aggravates the salinization of river water, with water quality evolving to saline conditions in the lower reach. When the river reaches the valley plain, the $87 \mathrm{Sr} / 86 \mathrm{Sr}$ ratios decreases significantly, which is primarily related to erosion of the riverbanks during runoff. These results indicate that water resource sustainability could be enhanced by directing focus to mitigating salinization in the source area of the catchment.
\end{abstract}

Significance of isotopic and geochemical methods to determine the evolution of inland brackish and bitter water: an example from the Zuli river in the upper reaches of the Yellow River, China

\section{Abstract}

With the increasing demand for water resources, the utilization of marginal water resources of poor-quality has become a focus of attention. The brackish water developed in the Loess Plateau is not only salty but also famous for its "bitterness". In the present work, multi-isotope analysis (Sr, B) was combined with geochemical analysis to gain insight into the hydrogeochemical evolution and formation mechanisms of brackish water. These results demonstrate that groundwater in the headwater is influenced by carbonate weathering. After the confluence of several tributaries in the headwater, the total dissolved solids (TDS) of water is significantly increased. The dissolution of evaporates is shown to be the main source of salinity in brackish water, which also greatly affects the Sr isotopic composition of water. This includes the dissolution of Mg-rich minerals, which is the main cause of the bitterness. Furthermore, the release of calcium from the dissolution of gypsum may induce calcite precipitation and incongruent dissolution of dolomite, which also 
contributes to the enrichment of magnesium. The highly fractionated boron isotopic values observed in the upstream groundwater were explained by boron interacting with clays, illustrating the important role played by the cationic exchange reaction. The inflow of brackish groundwater is the source of the observed quality of the river water. River water with relatively enriched ${ }^{11} \mathrm{~B}$ contents reflects the occurrence of evaporation along the flow path of the river. This process further aggravates the salinization of river water, with water quality evolving to saline conditions in the lower reach. When the river reaches the valley plain, the ${ }^{87} \mathrm{Sr} /{ }^{86} \mathrm{Sr}$ ratios decreases significantly, which is primarily related to erosion of the riverbanks during runoff. These results indicate that water resource sustainability could be enhanced by directing focus to mitigating salinization in the source area of the catchment.

Key words : Water salinization; Strontium isotope; Boron isotope; Geochemical tracers; Inland river catchment.

\section{Introduction}

The region of the Loess Plateau in China comprises an inland area with limited freshwater resources and a considerable amount of brackish water resources. The brackish water resource is valuable to the irrigated agricultural in this region. However, the formation mechanism of this water resource remains unclear, which is constraining the rational utilization of brackish water. (Luo, Chen, \& Han, 2010). Numerous studies have been conducted over the past several decades to assess the origin of brackish groundwater on a regional scale (Barth, 1998; Brenot, Négrel, Petelet-Giraud, Millot, \& Malcuit, 2015; Cartwright, 2004; Cary et al., 2015; Jørgensen, Andersen, \& Engesgaard, 2008; Werner et al., 2013; Sahib, Marandi, \& Schüth, 2016). Most of these previous studies were focused on the coastal areas, where the formation of saline groundwater was usually related to seawater intrusion. With the increasing water demand, there is increasing study and focus on the formation of brackish water in inland areas, where the geological contexts and hydrological conditions are more complex than coastal areas (Farid, Zouari, Rigane, \& Beji, 2015; Gamboa, Godfrey, Herrera, Custodio, \& Soler, 2019; Gil-Márquez, Barberá, Andreo, \& Mudarra, 2017). The sustainable management of inland brackish water resources is a global issue and requires a thorough assessment of the formation mechanism of brackish water (Alcalá \& Custodio, 2008; Cartwright, 2004; Cary et al., 2015; Ghassemi, Jakeman, \& Nix, 1995; Gil-Márquez et al., 2017; Monjerezi, Vogt, Aagaard, Gebru, \& Saka, 2011).

The Zuli River is a first-order tributary of the Yellow River, which is located in the western Loess Plateau. Except in the headwater, the groundwater and surface water in this catchment are both brackish, with a characteristic of "bitterness". Bitterness is an important factor affecting the quality and usability of water resources, particularly in inland areas (Gil-Márquez et al., 2017). However, few studies have been conducted to investigate the formation mechanism of bitterness in water.

Our previous study showed that groundwater recharge in the Zuli River catchment is produced by the infiltration of precipitation in the headwaters (Liu, Tan, Shi, Xu, \& I.Elenga, 2019). During this recharging process, the upstream groundwater undergoes rapid salinization. Several hypotheses have been advanced in previous studies as to the source of salinity in brackish water. Current knowledge typically attributes the salinization of groundwater in most inland areas to the mixing of old groundwater in deep strata (Herrera et al., 2018), which usually means the salinity of groundwater originated from long periods of water-rock interactions (Petrides, Cartwright, \& R.Weaver, 2006; Skrzypek, Dogramaci, \& F.Grierson, 2013). However, our recent study showed that even under the rapid renewal of groundwater, the fresh groundwater from the headwaters still evolves into brackish water with rapid salinization (Liu et al., 2019). Several hypotheses have been advanced in previous studies as to the source of salinity in brackish water. The large amounts of soluble salts in loess were identified as a potential source of salinity (Luo et al., 2010). The contribution of other hydrogeochemical processes still needs to be considered comprehensively, especially the origin of the bitterness.

The shortage of freshwater resources in many areas has led to the use of brackish water resources for agriculture in the Zuli River catchment. The long-term utilization of this poor-quality water resources has severely restricted local economic development. In recent years, the government launched several agricultural 
water conservancy projects, such as "The Taohe River Diversion Project" and "The Yellow River Diversion Project " that divert freshwater flow into the Zuli River for the dilution of saline river water, but they had minimal impact. How to optimize water resources in a cost-effective and sustainable manner is a critical question for this area.

The present contribution uses an integrated approach of geochemical and isotopic analysis to identifying the origins of salinity and evaluating salinization processes. The general water chemical methods are difficult to discriminate the source of solutes in groundwater precisely. Research increasingly suggests that a multiisotope approach is necessary to resolve the outstanding source of solutes in water (Cary et al., 2015; Gamboa et al., 2019; Jørgensen et al., 2008). Such an approach has been shown to be more effective in characterizing hydrogeochemical processes (Bullen, Krabbenhoft, \& Kendall, 1996; Cartwright, Weaver, Cendón, \& Swane, 2010; Cary et al., 2015; Harrington \& Herczeg, 2003). The study uses strontium isotopes and boron isotopes to investigate the possible processes responsible for the formation of brackish water. As a relatively stable element, strontium isotopes are minimally fractionated in chemical and biochemical processes. Groundwater in equilibrium with Sr-bearing minerals attains ${ }^{87} \mathrm{Sr} /{ }^{86} \mathrm{Sr}$ values that reflect the isotopic ratio of the minerals, leading to variation of the strontium isotopic ratio in different settings (Harrington \& Herczeg, 2003; Monjerezi et al.,2011; Sahib et al., 2016). Therefore, the ${ }^{87} \mathrm{Sr} /{ }^{86} \mathrm{Sr}$ ratio is classically used to provide information on the water-rock interaction under different geological contexts (Bullen et al., 1996; Brenot et al., 2015; Cartwright, 2004; Cartwright et al., 2010; Monjerezi et al., 2011; Palmer \& Edmond, 1992; Pingitore \& Eastman, 1986). On the contrary, boron is a relatively reactive element and mainly enriched in various types of rocks and water. Due to the isotopic distinctions, boron isotopes are prone to fractionate in many geochemical processes because of the larger relative difference in mass between its primary isotopes (Palmer, Spivack, \& Edmond, 1987; Vengosh, Heumann, Juraske, \& Kasher, 1994). Boron isotopes have been gradually applied to distinguish the original solute sources in groundwater, such as marine sources with enriched $\delta^{11} \mathrm{~B}$ values and continental sources with significantly depleted $\delta^{11} \mathrm{~B}$ values (Barth, 1998; Palmer \& Swihart, 1996; Vengosh, 2005). Therefore, boron isotope is also an effective tracer for understanding the geochemical evolution processes on a regional scale (Barth, 1993; Cary et al., 2015; Morell et al., 2008; Palmer et al., 1987; Vengosh et al., 1994). Thus, the combination of boron and strontium isotopes can be used more precisely to understand the hydro-geochemical evolution processes in the groundwater system on a regional scale. To our knowledge, this study is the first to report on the strontium isotopes of brackish water as well as the boron isotopes of local precipitation, river water, and groundwater from the study area. It is anticipated that the results obtained herein will fill in that gap in the isotope study of the Loess Plateau.

\section{Study area}

The Zuli River is a first-order tributary of the Yellow River. The total length of this river is 224 kilometers, and the annual runoff is nearly about $1.19 \times 10^{8} \mathrm{~m}^{3}$. The Zuli River Catchment occupies $10,653 \mathrm{~km}^{2}$ of the western Loess Plateau. The Zuli river originates from the Huajialing Mountain area and is composed of the $\mathrm{Zu}$ and Li Rivers (Fig. 1). The main tributary of the Zuli River is the Guanchuan River (Fig. 1).

The Zuli River Catchment can be classified as an arid-semi arid climate zone. Temperatures in the whole catchment (Huining weather station in the midstream area; Fig.1) shows highly seasonal variations (Fig.2a). The climate is characterized by cold winters with a mean temperature of -6.3 and warm summers with a mean temperature of 18.9. The mean multi-annual precipitation recorded from 2005 to 2019 in the Huining weather station is about $387.1 \mathrm{~mm}$ (Fig.2b). Affected by the continental monsoon, the annual precipitation in the Zuli River catchment is mainly dominated by summer rainfall from May to August (Fig.2a). With respect to precipitation, the mean annual potential evaporation is about $1800 \mathrm{~mm}$ and is nearly five times greater than the mean annual precipitation in the Zuli River catchment (Luo et al., 2010).

The Huajialing Mountain area is the source region of the Zuli River Catchment, which is also the watershed between the Zuli River and the Weihe River. Thick layers Silurian carbonate rocks are deposited in this area (Fig.3a), affected by large-scale tectonic activity, joints and fissures were developed in the strata of headwater. Additionally, karstic features have developed, and fissure water and bedrock fissure water are present in the fracture zone (Liu et al., 2019). 
The Zuli River Catchment is a typical hilly area on the Loess Plateau. This river is located in the canyon area, with an altitude ranging from 1396 to $2377 \mathrm{~m}$ (Fig. 3). The geological strata of the Zuli River Catchment can be divided into three main units. Simplified geology with major structural characteristics of the Zuli River catchment is displayed in Fig. 3. The basement is constituted by Silurian carbonate rocks, Cretaceous clastic rocks and Permian monzonitic granite (Fig. 3a). A Tertiary red clay layer and the Quaternary loess layer are deposited successively in the basement (Fig. 3b). A large amount of soluble minerals exists in the loess, such as halite, gypsum, etc (Tsunekawa, Liu, Yamanaka, \& Du, 2014; Fan et al., 2016; Xiao, Zhang, \& Jin, 2016).

\section{Materials and methods}

A total of 63 samples were collected from the Zuli River Catchment and these samples were divided into five types: precipitation $(n=5)$, groundwater $(n=20)$, river water $(n=25)$, soil, and river suspended particulates $(\mathrm{n}=13)$ (Fig. 1). Local precipitation of headwaters was sampled monthly from May to September for one season (Fig. 1). TDS and $\mathrm{pH}$ measurements were performed in the field with a calibrated portable MultiParameter Analyzer (HACH HQ40D; typical EMC deviation: $+-0.1 \mathrm{pH},+-1 \%$ of TDS). Water samples were filtered in the field at $0.45 \mu \mathrm{m}$ for hydrochemistry analyses and acidified for cations and ${ }^{87} \mathrm{Sr} /{ }^{86} \mathrm{Sr}$ analysis to $\mathrm{pH}<2$ with ultrapure $\mathrm{HNO}_{3}$. For the hydrochemistry analysis, the water samples with TDS $>1000 \mathrm{mg} / \mathrm{l}$ were diluted to TDS less than $500 \mathrm{mg} / \mathrm{l}$. Samples for Boron isotopic analysis were collected in a separate bottle.

All chemical compositions of the samples $(\mathrm{n}=50)$ were analyzed at the State Key Laboratory of HydrologyWater Resources and Hydraulic Engineering, Hohai University, China. Major cations were analyzed by inductively coupled plasma-atomic emission spectrograph (ICP-AES) (Instrumental Error $<5.0 \%$ ), and major anions were analyzed by ion chromatography (ICS-2000) (Instrumental Error $<2.0 \%$ ).

For strontium isotopes, the isotopic compositions of $\mathrm{Sr}(\mathrm{n}=18$; Table 1$)$ were determined by TIMS (Thermal Ionization Mass Spectrometry, Triton, VG354) with nine Faraday collectors at the Institute of Geochemistry, Nanjing Nantai. The ${ }^{87} \mathrm{Sr} /{ }^{86} \mathrm{Sr}$ value for the standard NIST987 was $0.710236 \pm 0.000007(2 \mathrm{r}, \mathrm{n}=62)$ during the measurement period of our samples. The total blank for Sr was less than $0.5 \mathrm{ng}$, negligible with respect to the total strontium in the analyzed precipitation samples.

Boron isotopes ( $\mathrm{n}=28$; Table 1) were analyzed using a Neptune Plus MC-ICP-MS (Nanjing) with an ESI PFA $50 \mu \mathrm{L} /$ min nebulizer in a quartz cyclonic spray chamber. The isotopic standard $\left({ }^{11} \mathrm{~B} /{ }^{10} \mathrm{~B}\right)$ standard NIST 951 $=4.04362$. To reduce the memory effect, continuous washing with $3 \% \mathrm{HNO}_{3}$ and $1 \% \mathrm{HNO}_{3}$ and Millipore water in sequence for ${ }^{\sim} 25$ min was conducted. The final isotopic compositions are reported as $\delta^{11} \mathrm{~B}=1000$ $\left(\mathrm{R}_{\text {sample }} / \mathrm{R}_{\text {standard }}-1\right)$. The average internal analytical precision $(\mathrm{n}=100)$ and the external reproducibility of the measured ${ }^{11} \mathrm{~B} /{ }^{10} \mathrm{~B}$ ratios of $200 \mathrm{ng} / \mathrm{mL}$ NIST 951 are \pm 0.02

\section{Results}

The chemical parameters, ${ }^{87} \mathrm{Sr} /{ }^{86} \mathrm{Sr}$ ratios and $\delta^{11} \mathrm{~B}$ values of the analyzed samples are given in Table 1 . The $\mathrm{pH}$ in water samples shows a narrow range (7.32-8.85), with a mean value of $8.08 \pm 0.36$ (Table 1$)$. The TDS of all water samples varied considerably from 356.7 to $11296 \mathrm{mg} / \mathrm{l}$ (Table 1), with a general increase from the source region to downstream. The source groundwater with low TDS is dominated by $\mathrm{Mg}-\mathrm{Ca}-\mathrm{Na}-\mathrm{HCO}_{3}$ type, while the upstream groundwater and river water were saline water with a $\mathrm{Na}-\mathrm{Mg}$-Cl- $\mathrm{SO}_{4}$-type facies. $\mathrm{Cl} / \mathrm{Br}$ ratios of source groundwater samples ranged from 409.0 to 519.3. The upstream groundwater and river water samples had a relatively steady trend of $\mathrm{Cl} / \mathrm{Br}$ ratios, ranging from 1242 to 2405 . Ca and $\mathrm{Mg}$ concentrations of these water samples are well correlated to $\mathrm{SO}_{4}$, with $(\mathrm{Ca}+\mathrm{Mg}) / \mathrm{SO}_{4}$ ratio of most saline water samples close to 1 . The $\mathrm{Mg} / \mathrm{Ca}$ ratio of saline water samples generally exceeds 1 , which indicates the enrichment of $\mathrm{Mg}$ with water salinization.

Strontium concentrations and ${ }^{87} \mathrm{Sr} /{ }^{86} \mathrm{Sr}$ ratios in groundwater ranged from 0.5 to $9.9 \mathrm{mg} / \mathrm{l}$, and from 0.710903 to 0.711784 , respectively. The upstream groundwater samples had a higher strontium concentration and higher ${ }^{87} \mathrm{Sr} /{ }^{86} \mathrm{Sr}$ ratios than source groundwater. The strontium concentration of river water samples varied 
between 4.2 and $11.1 \mathrm{mg} / \mathrm{l}$, with ${ }^{87} \mathrm{Sr} /{ }^{86} \mathrm{Sr}$ ratios between 0.710916 and 0.711427 . The river water presents higher Sr contents and lower ${ }^{87} \mathrm{Sr} /{ }^{86} \mathrm{Sr}$ values compared to that of upstream groundwater (Table 1). The Strontium concentrations are in a relatively narrow range (0.23-0.53) in the soil samples (water-soluble) collected from riverbanks, while the ${ }^{87} \mathrm{Sr} /{ }^{86} \mathrm{Sr}$ ratio varied between 0.710912 and 0.713937 with an increasing trend from mountaintop to the foothills. Strontium correlated well with Calcium and Chlorine in brackish water samples. The $\mathrm{Sr} / \mathrm{Cl}$ ratio of source groundwater samples ranged from 0.034 to 0.036 and is significantly higher than that of the upstream groundwater (0.002-0.007). The $\mathrm{Sr} / \mathrm{Ca}$ ratio of water samples also presents a systematic increase with water salinization.

Values of $\delta^{11} \mathrm{~B}$ in water are highly variable and ranged from -5.79 and from +17 .45the upstream groundwater and the river water, respectively. The Boron isotope ratios of the river water samples displayed a broader range (17.45(Table 1$)$, but still lower than the $\delta^{11} \mathrm{~B}$ values of seawater $\left(39.5 \pm 1\right.$ particulates samples had $\delta^{11} \mathrm{~B}$ values of 3.505.42profiles under water and acid treatment were from -2.13 from 0.60

\section{Discussion}

\subsection{Formation of saline water}

\subsubsection{Formation of freshwater in headwater}

The strata of the mountain area in the headwater of the Zuli River are mainly composed of a set of marine carbonate rocks (Zhan et al., 2010). In our previous study, groundwater was considered as recharged by precipitation in the headwaters based on the analysis of stable isotopes data $\left(\delta^{2} \mathrm{H}, \delta^{18} \mathrm{O}\right)$ (Liu et al., 2019). The groundwater in the headwater region is characterized by higher strontium concentration and ${ }^{87} \mathrm{Sr} /{ }^{86} \mathrm{Sr}$ ratios relative to those determined for precipitation (strontium concentrations: $(0.002-0.3 \mathrm{mg} / 1){ }^{87} \mathrm{Sr} /{ }^{86} \mathrm{Sr}$ ratio:0.7078-0.7092 (Bullen et al., 1996))(Table 1). This suggests that there is dissolution of Sr-containing minerals in the source groundwater, with this process increasing the strontium concentration and affecting the strontium isotopic composition of water. The higher $\mathrm{Sr} / \mathrm{Cl}$ ratio in source groundwater probably reflects rock weathering as an important control of the chemical composition of groundwater with low TDS (Monjerezi et al., 2011) (Fig. 5b). The $\mathrm{Sr} / \mathrm{Cl}$ ratio and the ${ }^{87} \mathrm{Sr} /{ }^{86} \mathrm{Sr}$ ratio show an inverse correlation in the source groundwater (Fig.5b). The inverse correlation between the $\mathrm{Sr} / \mathrm{Cl}$ ratio and ${ }^{87} \mathrm{Sr} /{ }^{86} \mathrm{Sr}$ ratio is generally related to the significant dissolution of carbonate minerals (Harrington \& Herczeg, 2003). This process is also supported by the ${ }^{87} \mathrm{Sr} /{ }^{86} \mathrm{Sr}$ ratio of source groundwater $(0.710903-0.711041$, NO.2,4) compatible with the signature of limestone $\left({ }^{87} \mathrm{Sr} /{ }^{86} \mathrm{Sr}: 0.709-0.713\right)$ (Cartwright et al., 2010) (Table 1).

Studies focusing on boron isotopic composition in precipitation in the Loess Plateau are sparse. In this work, the source groundwater (Sample NO. 1-2) shows lighter boron isotopic composition than precipitation (Sample NO. 46-50) (Table 1), which may indicate that there is an input of boron with low $\delta^{11} \mathrm{~B}$ value in source groundwater. In the mountain area of headwater, there are many exposed carbonatite rocks (Zhan et al., 2010). The narrow range of $\delta^{11} \mathrm{~B}$ variation in the source groundwater (-8.35NO.1-2) can be attributed to carbonate rock weathering in which $\delta^{11} \mathrm{~B}$ values usually range from -15Swihart, 1996; Romer, Meixner, \& Förster, 2014). Due to the conservative property of chloride and bromide, the $\mathrm{Cl} / \mathrm{Br}$ ratio (weight) was used as an indicator to judge the source of salinity in groundwater, especially in distinguishing between marine and non-marine (Cartwright, 2004; Edmunds, Ma, Aeschbach-Hertig, Kipfer, \& Darbyshire, 2006). In this study, the $\mathrm{Cl} / \mathrm{Br}$ ratio of groundwater in headwater is similar or slightly higher than that of seawater (Alcalá \& Custodio, 2008) (Fig. 4a), suggesting these ions are of marine origin (Skrzypek et al., 2013). These above characteristics indicate that the dissolution of carbonate minerals is the main process that influences the geochemical and isotopic composition of groundwater in headwater.

\subsubsection{Formation of brackish groundwater in the upstream}

The upstream groundwater shows an obvious salinization than groundwater in headwater. The TDS in upstream groundwater varies from 1177 to $8216 \mathrm{mg} / \mathrm{l}$ (Table 1), which is classified as brackish water (Freeze \& Cherry, 1979). According to the previous work, the upstream groundwater is recharged by groundwater in headwater and precipitation. And the tritium data shows a rapid circulation of groundwater (less than 40 
years) in the upstream area (Liu et al., 2019). Groundwater still evolves to brackish water from headwater to the upstream area under such a rapid replenishing, which is rare in most similar inland areas around the world.

The $\delta^{11} \mathrm{~B}$ values of upstream groundwater are significantly lower than those of seawater (Barth, 1993), which indicates the geochemical composition in upstream groundwater is of non-marine origins (Fig. 7). The variation range of $\delta^{11} \mathrm{~B}$ value in these water load samples (3.39NO.61-63) and soil samples (acid-extracted) (0.6in the range of $\delta^{11} \mathrm{~B}$ value for the non-marine evaporates (Vengosh et al., 1994) (Table 1) (Fig. 7). The boron isotopic characteristic indicates that the dissolution of non-marine evaporates is the possible source of solutes in brackish groundwater.

In the quaternary loess layers of the study area, there are reserves a large amount of soluble evaporates minerals (Tsunekawa et al., 2014; Xiao et al., 2016), such as halite, gypsum, etc. The increase of strontium concentration and ${ }^{87} \mathrm{Sr} /{ }^{86} \mathrm{Sr}$ ratio observed in upstream groundwater relative to the source groundwater (Fig. 5a) implies that there exists a strontium input with higher ${ }^{87} \mathrm{Sr} /{ }^{86} \mathrm{Sr}$ ratio during the evolution of groundwater. However, there is no correlation between $\mathrm{Sr} / \mathrm{Cl}$ ratio and $\mathrm{Sr}$ isotopic composition in upstream groundwater (Fig. 5b), as would be suggested weathering of carbonates rocks is no longer the major geochemical process in water. Strontium and calcium belong to one family and strontium usually reserve in Ca-containing minerals (Yokoo, Nakanob, Nishikawac, \& Quan, 2004). Strontium shows a significant correlation with calcium $\left(\mathrm{R}^{2}=0.9037\right.$; Fig. 5c) in upstream groundwater, which means strontium origin from the dissolution of Ca-containing mineral in the evolution of groundwater. The ${ }^{87} \mathrm{Sr} /{ }^{86} \mathrm{Sr}$ ratios of upstream groundwater are close to those reported for aquifers where evaporates dissolution occurs (0.711; Palmer \& Edmond, 1992). Therefore, the dissolution of gypsum mineral is the main source of strontium, which also is an important source of solutes in upstream water.

When there is a dissolution of non-marine evaporates mineral, the $\mathrm{Cl} / \mathrm{Br}$ ratio will significantly increase with the increase of chloride concentration in water (Brenot et al., 2015). The $\mathrm{Cl} / \mathrm{Br}$ vs. Cl diagram displays a well-defined relationship between these two conservative indicators in the upstream groundwater and $\mathrm{Cl} / \mathrm{Br}$ ratio of upstream groundwater shows obvious high relative to that of source groundwater (Fig. 4a), indicating progressive reaction derived from the dissolution of non-marine evaporates with high $\mathrm{Cl} / \mathrm{Br}$ ratio during the evolution of groundwater. With the increase of $\mathrm{Cl} / \mathrm{Br}$ ratio, the $\mathrm{Na} / \mathrm{Cl}$ ratio of groundwater samples gradually approaches 1 (Fig. 4b), which clearly argues for the dissolution of halite mineral as an important source of salinity in groundwater.

Nevertheless, the $\delta^{11} \mathrm{~B}$ values of upstream groundwater samples (11.48those of water affecting by non-marine evaporates dissolution (-32(Vengosh et al., 1994) (Fig. 7), meaning that the boron isotopic signature is altered by additional B inputs from other sources beyond the dissolution of non-marine evaporates. Indeed, the loess layer is rich in clay minerals which have a high cation exchange capacity (Cartwright, Weaver, \& Petrides, 2007; Tsunekawa et al., 2014), such as kaolinite and illite. This characteristic usually promotes cationic exchange reaction to be active in groundwater (Ghassemi et al, 1995). The preferential ${ }^{10} \mathrm{~B}$ adsorption occurs on exchange phases (clay minerals), while the ${ }^{11} \mathrm{~B}$ will remain in the liquid phase (groundwater), which will lead to the relative enrichment of ${ }^{11} \mathrm{~B}$ in water (Palmer et al., 1987). Since chloride behaves as a conservative element, the low $\mathrm{B} / \mathrm{Cl}$ ratio usually reflects a loss of boron related to the preferential adsorption of ${ }^{10} \mathrm{~B}$ in cation exchange (Cary et al., 2015). The $\mathrm{B} / \mathrm{Cl}$ ratio gradually decreased with the increase of TDS in upstream groundwater also reflect the existence of the cation exchange reaction (Fig. 6b).

As suggested above, the dissolution of non-marine evaporates is the main source of solutes in the upstream groundwater. These soluble minerals can dissolute into water rapidly during the flow path of groundwater and lead to the salinization of water. In addition, the cation exchange reaction occurs in the upstream groundwater significantly modify the boron isotopic signature of water, which also influence the geochemical composition of water.

\subsubsection{Further salinization of river water}

After being recharged by brackish groundwater, the river water shows further salinization, with a higher 
strontium concentration, lower ${ }^{87} \mathrm{Sr} /{ }^{86} \mathrm{Sr}$ ratios (Fig. 5a) and a much heavier boron isotopic composition relative to groundwater. Few river samples (NO.44-45) even evolve to saline water (TDS ¿10000 mg/l).

Because of chloride and bromide are conservative elements with similar geochemical behavior, evaporation would not change the $\mathrm{Cl} / \mathrm{Br}$ ratio of water (Brenot et al., 2015). The river water shows a higher TDS compared to groundwater (Table 1), but the variation of the $\mathrm{Cl} / \mathrm{Br}$ ratio of river water still keeps steadily (Fig. 4a), which implies that evaporation imparts a significant influence on the salinization of the river water. Under the condition of airflow, evaporation will cause the light ${ }^{10} \mathrm{~B}$ in the water to enter the vapor phase preferentially, while ${ }^{11} \mathrm{~B}$ will remain in the liquid phase (Barth,1993), thus resulting in an enrichment of ${ }^{11} \mathrm{~B}$ in water (Fig. 6a). Therefore, the heavier boron isotopic composition of river water can also attribute to evaporation.

According to the above discussion, the further increase of strontium concentration in river water compared to groundwater can be attributed to the concentrating by evaporation. However, the ${ }^{87} \mathrm{Sr} /{ }^{86} \mathrm{Sr}$ ratio in river water shows a decreasing trend, which indicates there is additional strontium input in river water (Fig. 5a). These soil samples collected from the hillside is contained strontium with a lower ${ }^{87} \mathrm{Sr} /{ }^{86} \mathrm{Sr}$ ratio $(0.710912$ 0.711110, Table 1; Fig. 5a). And these soil profile samples (water-extracted) collected from one site where adjoin to the riverbanks also exhibit a depleted boron isotope (-2.13 soil (NO.55-56) relative to the deeper soil (NO.57) (Table 1). These characteristics suggest the occurrence of soil erosion events in the runoff of the river, which includes the leaching process along the riverbanks, and the infiltration process occurring on the hillside in precipitation events. These processes provide additional salts and strontium with a lower ${ }^{87} \mathrm{Sr} /{ }^{86} \mathrm{Sr}$ ratio for the river, which also leached a large amount of ${ }^{11} \mathrm{~B}$ in the upper soil layer into the river water.

\subsection{Formation of bitter water}

Magnesium sulfate mineral is nicknamed "bitter salt" in mineralogy (Maik, Redel, Blank, \& Meyerhof, 2019). This is because water solution with high magnesium concentration usually exhibits a taste of bitterness (Maik et al., 2019). The brackish water in the study area is most of the $\mathrm{Na}-\mathrm{Mg}-\mathrm{Cl}-\mathrm{SO}_{4}$ type, which indicates the magnesium is the one of major cations in water. Bitterness is another typical feature of the brackish water in the Zuli River Catchment.

According to the above discussion, the dissolution of carbonate minerals exists in groundwater of headwater. The Mg vs. Ca diagram (Fig. 8b) shows groundwater samples in headwater were close to the 1:1 line, which indicates that the occurrence of dolomite dissolution in source groundwater. Then with the evolution of water, there is a considerable enrichment in magnesium compared to calcium in upstream groundwater and river water (Fig. 8b), implying that there must be an additional source(s) of magnesium besides carbonates dissolution in the brackish water.

In the $(\mathrm{Ca}+\mathrm{Mg})$ vs. $\mathrm{SO}_{4}$ diagram, the distribution of groundwater samples maintains a good linear relationship (Fig. 8a), reflecting the theoretical dissolution of sulfated minerals containing calcium and magnesium. Although sulfate minerals bearing magnesium, such as epsomite $\left(\mathrm{MgSO}_{4} * 7 \mathrm{H}_{2} \mathrm{O}\right)$ or hexahydrate $\left(\mathrm{MgSO}_{4} * 6 \mathrm{H}_{2} \mathrm{O}\right)$, are not the main composition of minerals in the Zuli River Catchment (Tsunekawa et al., 2014; Fan et al., 2016). But their existence at depth, even in small quantities, could explain the good linear relationship between $(\mathrm{Ca}+\mathrm{Mg})$ and $\mathrm{SO}_{4}$ in the brackish water. Those minerals are characterized by high solubility, which can permit a faster dissolution process and a great impact on the magnesium concentration of water (Márquez et al., 2017). The dissolution of these magnesium sulfate minerals is the initial and most important source of magnesium in brackish water and result in the brackish water to be bitterness.

According to the above discussion, the dissolution of gypsum is an important source of salinity in brackish water, and the rise of gypsum-derived solutes $\left(\mathrm{Ca}^{2+}\right.$ and $\left.\mathrm{SO}_{4}{ }^{2-}\right)$ along with the salinization of water. Due to these carbonate minerals has reached saturation in brackish water, which was reported in the previous study (Liu et al., 2019). Then with $\mathrm{Ca}^{2+}$ continuously entering the water, incongruent dolomite dissolution and calcite precipitation are driven by gypsum dissolution due to the common ion effect (Appelo \& Postma, 1993; Edmunds, Bath, \& Miles, 1982). These processes also lead to the further enrichment of magnesium in water, serving as another important source of magnesium. This process is occurring in groundwater according to 
this reaction:

$\mathrm{CaMg}\left(\mathrm{CO}_{3}\right)_{2}(\mathrm{~S})+\mathrm{H}_{2} \mathrm{CO}_{3}-\mathrm{Ca}\left(\mathrm{CO}_{3}\right)(\mathrm{S})+\mathrm{Mg}^{2+}+2 \mathrm{HCO}_{3}{ }^{-}$。

The increase of the $\mathrm{Sr} / \mathrm{Ca}$ ratio and the characteristics of $\mathrm{Sr}$ isotope in groundwater also confirms the existence of this process. It is interfered with $\mathrm{Sr}$ isotopes that strontium mainly originates from the dissolution of gypsum, and this process usually reduces the Sr/Ca ratio (Cartwright et al., 2007). But with the salinization of groundwater, the $\mathrm{Sr} / \mathrm{Ca}$ ratio of upstream groundwater is also increasing (Fig. 8c). This is because when strontium, like calcium, precipitates from solution into calcite, the strontium is more inclined to retain in solution compared to calcium (Pingitore \& Eastman, 1986). Therefore, precipitation of carbonate minerals tends to increase the $\mathrm{Sr} / \mathrm{Ca}$ ratio in the residual water due to the rejection of strontium in preference for calcium in carbonates (Monjerezi et al., 2011).

\section{Conclusion}

This study has presented a comprehensive understanding of the primary geochemical processes that occur in an inland catchment of the Loess Plateau, based on an integration of information derived from the chemical and isotopic signatures of water and soil. Therefore, we conclude that: 1) Affected by the carbonate formation, the $\mathrm{Mg}-\mathrm{Ca}-\mathrm{Na}-\mathrm{HCO}_{3}$ type groundwater is formed in the headwater. Groundwater in the headwater is also characterized by a lower ${ }^{87} \mathrm{Sr} /{ }^{86} \mathrm{Sr}$ and depleted $\delta^{11} \mathrm{~B}$ value. The dissolution of non-marine evaporites, such as halite and gypsum, is the main source of salinity in brackish groundwater of upstream, and these processes also contribute the strontium ions with high ${ }^{87} \mathrm{Sr} /{ }^{86} \mathrm{Sr}$ ratios and the boron ions with high $\delta^{11} \mathrm{~B}$ value into water. Additionally, the cation exchange reaction occurs in upstream groundwater has a significant influence on the geochemical composition of water and resulting in a much heavier boron isotopic composition of water. After recharged by brackish groundwater, the river water was affected by evaporation and various soil erosion events during runoff. Then the river water showed further salinization, decease of ${ }^{87} \mathrm{Sr} /{ }^{86} \mathrm{Sr}$ ratios, and enrichment in heavy boron isotopes.

2) The magnesium sulfate minerals in loess provide an initial source for magnesium enrichment in upstream groundwater. In addition, the incongruent dissolution of dolomite coupled with gypsum dissolution and calcite precipitation also contributed to the enrichment of magnesium in groundwater. In addition to the impact of brackish groundwater, the river water is further affected by evaporation, which enhance the level of "bitterness".

These results indicate that water salinization in the Zuli River catchment primarily originates from the dissolution of soluble minerals in the upstream area, large-scale treatment for the brackish water resources in the downstream area should be avoided, instead of strengthening the water treatment in front of the mountain pass or exploration of the high-quality groundwater in the headwater should be encouraged.

\section{Acknowledgments}

This study was supported by the National Natural Science Foundation of China (41271041) and the Fundamental Research Funds for the Central Universities (2019B60514). The authors gratefully acknowledge financial support from China Scholarship Council.

\section{Data Availability Statement}

The data that support the findings of this study are available from the corresponding author upon reasonable request.

\section{References}

Alcalá, F., \& Custodio, E. (2008). Using the $\mathrm{Cl} / \mathrm{Br}$ ratio as a tracer to identify the origin of salinity in aquifers in Spain and Portugal. J. Hydrol., 359(1-2), 189-207.

Appelo, C.A.J., \& Postma, D. (1993). Geochemistry, Groundwater and Pollution. A.A. Balkema, Rotterdam, $536 \mathrm{p}$. 
Barth, S. (1993). Boron isotope variations in nature: A synthesis. Geol. Rundsch., 82, 640-65.

Barth, S. (1998). ${ }^{11} \mathrm{~B} /{ }^{10} \mathrm{~B}$ Variations of Dissolved Boron in a Freshwater/Seawater Mixing Plume (Elbe Estuary, North Sea). Marine Chem., 62, 1-14.

Bullen, T.D., Krabbenhoft, D.P., \& Kendall, C. (1996). Kinetic and mineralogic controls on the evolution of groundwater chemistry and ${ }^{87} \mathrm{Sr} /{ }^{86} \mathrm{Sr}$ in a sandy silicate aquifer, northern Wisconsin, USA. Geochim. Cosmochim. Acta, 60(10), 1807-1821.

Brenot, A., Négrel, P., Petelet-Giraud, E., Millot, R., \& Malcuit, E. (2015). Insights from the salinity origins and interconnections of aquifers in a regional scale sedimentary aquifer system (Adour-Garonne district, SW France): Contributions of $\delta^{34} \mathrm{~S}$ and $\delta^{18} \mathrm{O}$ from dissolved sulfates and the ${ }^{87} \mathrm{Sr} /{ }^{86} \mathrm{Sr}$ ratio. Appl. Geochem., $53,27-41$.

Cartwright, I. (2004). Hydrogeochemical and isotopic constraints on the origins of dryland salinity, Murray Basin, Victoria, Australia. Appl. Geochem., 19(8), 1233-1254.

Cartwright, I., Weaver, T., \& Petrides, B. (2007). Controls on ${ }^{87} \mathrm{Sr} /{ }^{86} \mathrm{Sr}$ ratios of groundwater in silicatedominated aquifers: SE Murray Basin, Australia. Chem. Geol., 246(1-2), 0-123.

Cartwright, I., Weaver, T., Cendón, D., \& Swane, I. (2010). Environmental isotopes as indicators of interaquifer mixing, Wimmera region, Murray Basin, Southeast Australia. Chem. Geol., 277(3-4), 0-226.

Cary, L., Petelet-Giraud, E., Bertrand, G., Kloppmann, W., Aquilina, L., Martins, V., Hirata, R., Montenegro, S., Pauwels, H., Chatton, E., Franzen, \& M., Aurouet, A. (2015). Origins and processes of groundwater salinization in the urban coastal aquifers of Recife (Pernambuco, Brazil): A multi-isotope approach. Sci. Total Environ., 530-531, 411-429.

Edmunds, W.M., Bath, A.H., \& Miles, D.L. (1982). Hydrochemical evolution of the East Midlands Triassic sandstone aquifer, England. Geochim. Cosmochim. Acta, 46(11), 2069-2081.

Edmunds, W.M., Ma, J.Z., Aeschbach-Hertig, W., Kipfer, R., \& Darbyshire, D.P.F. (2006). Groundwater recharge history and hydrogeochemical evolution in the Minqin Basin, North West China. Appl. Geochem., 21(12), 0-2170.

Farid, I., Zouari, K., Rigane, A., \& Beji, R. (2015). Origin of the groundwater salinity and geochemical processes in detrital and carbonate aquifers: Case of Chougafiya basin (Central Tunisia). J. Hydrol., 530, 508-532.

Fan, B.L., Zhao, Z.Q., Tao, F.X., Li, X.D., Tao, Z.H., Gao, S., \& He, M.Y. (2016). The geochemical behavior of $\mathrm{Mg}$ isotopes in the Huanghe basin, China. Chemical Geology, 426, 19-27.

Freeze, R.A., \& Cherry, J.A. (1979). Groundwater Prentice-Hall, Englewood Chffs, New Jersey.

Gamboa, C., Godfrey, L., Herrera C., Custodio E., \& Soler, A. (2019). The origin of solutes in groundwater in a hyper-arid environment: A chemical and multi-isotope approach in the Atacama Desert, Chile. Sci. Total Environ., 690, 329-351.

Ghassemi, F., Jakeman, A.J., \& Nix, H.A. (1995). Salinisation of land and water resources: Human causes, extent, management, and case studies. CAB International, Wallingford.

Gibbs, R. J. (1970). Mechanisms controlling world water chemistry. Science, 172(3985), 870-872.

Gil-Márquez, J.M, Barberá, J.A, Andreo, B., \& Mudarra, M. (2017). Hydrological and geochemical processes constraining groundwater salinity in wetland areas related to evaporitic (karst) systems. A case study from Southern Spain. J. Hydrol., 2017, 538-554.

Harrington, G.A., \& Herczeg, A.L., 2003. The importance of silicate weathering of a sedimentary aquifer in arid Central Australia indicated by very high ${ }^{87} \mathrm{Sr} /{ }^{86} \mathrm{Sr}$ ratios. Chem. Geol., 199(3), 281-292. 
Herrera, C., Gamboa, C., Custodio, E., Jordan, T., Godfrey, L., Jódar, J., Luque, J.A., Vargas, J., \& Sáez, A. (2018). Groundwater origin and recharge in the hyperarid Cordillera de la Costa, Atacama Desert, northern Chile. Sci. Total Environ., 624, 114-132.

Jørgensen, N. O., Andersen, M. S., \& Engesgaard. P. (2008). Investigation of a Dynamic Seawater Intrusion Event using Strontium Isotopes $\left({ }^{87} \mathrm{Sr} /{ }^{86} \mathrm{Sr}\right)$. J. Hydrol., 348, 257-269.

Liu, Z.H., Tan, H.B., Shi, D.P., Xu, P., \& I.Elenga, H. (2019). Origin and formation mechanism of salty water in Zuli River catchment of the Yellow River. Water Environ. Res., 1, 1-17.

Luo, C.S., Chen, W.W., \& Han, W.F. (2010). Experimental study on factors affecting the quality of ice crystal during the freezing concentration for the brackish water. Desalination, 260(1-3), 231-238.

Maik, B., Redel, U., Blank, K., \& Meyerhof, W. (2019). The human bitter taste receptor TAS2R7 facilitates the detection of bitter salts. Biochem. Biophys. Res. Commun., 512, 877-881.

Monjerezi, M., D.Vogt, R., Aagaard, P., Gebru, A.G., \& Saka, J.D.K. (2011). Using ${ }^{87} \mathrm{Sr} /{ }^{86} \mathrm{Sr}, \delta^{18} \mathrm{O}$ and $\delta^{2} \mathrm{H}$ isotopes along with major chemical composition to assess groundwater salinization in lower Shire valley, Malawi. Appl. Geochem., 26(12), 0-2214.

Morell, I., Pulido-Bosch, A., Sánchez-Martos, F., Vallejos, A., Daniele, L., Molina, L., Calaforra, J.M., Roig, A.F., \& Renau, A. (2008). Characterization of the Salinisation Processes in Aquifers Using Boron Isotopes; Application to South-Eastern Spain. Water, Air, Soil Pollut., 187(1-4), 65-80.

Palmer, M.R., Spivack, A.J., \& Edmond, J.M. (1987). Temperature and pH controls over isotopic fractionation during adsorption of boron on marine clay. Geochim. Cosmochim. Acta, 51(9), 2319-2323.

Palmer, M.R., \& Edmond, J.M. (1992). Controls over the strontium isotope composition of river water. Geochim. Cosmochim. Acta, 56(5), 2099-2111.

Palmer, M.R., \& Swihart, G.H. (1996). Boron isotopes geochemistry: An overview. Boron: Mineralogy, Petrology and Geochemistry. Rev. Mineral. Geochem., 33, 709-744.

Petrides, B., Cartwright, I., \& R.Weaver, T. (2006). The evolution of groundwater in the Tyrrell catchment, south-central Murray Basin, Victoria, Australia. Hydrogeol. J., 14, 1522-1543.

Pingitore, N.E., \& Eastman, M.P. (1986). The coprecipitation of $\mathrm{Sr}^{2+}$ with calcite at $25^{\circ} \mathrm{C}$ and 1 atm. Geochim. Cosmochim. Acta, 50(10), 2195-2203.

Romer, R.L., Meixner, A., \& Förster, H. (2014). Lithium and boron in late-orogenic granites - Isotopic fingerprints for the source of crustal melts. Geochimica et Cosmochimica Acta, 131, 98-114.

Skrzypek, G., Dogramaci, S., \& F.Grierson, P. (2013). Geochemical and hydrological processes controlling groundwater salinity of a large inland wetland of northwest Australia. Chem. Geol., 357, 164-177.

Spivack, A.J., \& Edmond, J.M. (1987). Boron isotope exchange between seawater and the oceanic crust. Geochim. Cosmochim. Acta, 51, 1033-1043.

Tsunekawa, A., Liu, G., Yamanaka, N., \& Du, S. (2014). Restoration and Development of the Degraded Loess Plateau, China. Springer, Tokyo.

Vengosh, A., Heumann, K.G., Juraske, S., \& Kasher, R. (1994). Boron Isotope Application for Tracing Sources of Contamination in Groundwater. Environ. Sci. Technol., 28(11), 1968-1974.

Vengosh A. (2005). Salinization and saline environments [M]//Elsevier Science Technology: Treatise on geochemistry volume 9: Environmental Geochemistry, 168 -333.

Werner, A.D., Bakker, M., Post, V.E.A., Vandenbohede, A., Lu, C., \& Ataie-Ashtiani, B. (2013). Seawater intrusion processes, investigation and management: recent advances and future challenges. Adv. Water Resour. 51, 3-26. 
Sahib, L., Marandi, A., \& Schüth, C. (2016). Strontium isotopes as an indicator for groundwater salinity sources in the Kirkuk region, Iraq. Sci. Total Environ., 562, 935-945.

Xiao, J., Zhang, F., \& Jin, Z.D. (2016). Spatial characteristics and controlling factors of chemical weathering of loess in the dry season in the middle Loess Plateau, China. Hydrol. Process., 30, 4855-4869.

Yokoo, Y., Nakanob, T., Nishikawac, M., \& Quan, H. (2004). Mineralogical variation of Sr-Nd isotopic and elemental compositions in loess and desert sand from the central Loess Plateau in China as a provenance tracer of wet and dry deposition in the northwestern Pacific. Chem. Geol., 204, 45-62.

Zhan, T., Guo, Z.T., Wu, H.B., Ge, J.Y., Zhou, X., Wu, C.L., \& Zeng, F.M. (2011). Thick Miocene eolian deposits on the Huajialing Mountains: The geomorphic evolution of the western Loess Plateau. Sci. China: Earth Sci., 54, 241-248.

\section{Figure Legends}

Fig. 1 Location of sampling sites within the Zuli River Catchment.

Fig. 2 (a) Annual of total precipitation and mean temperature and (b) monthly variation of total precipitation in the center of the Zuli River catchment (data from Huining weather station) (The blue dashed line refers to annual mean total precipitation in the past 15 years from 2005 to 2019).

Fig. 3 (a) Schematic geological map of the Zuli river catchment and (b) simplified hydrogeological crosssection along with the mainstream of Zuli river (topographical profile A-A' corresponding to the line in the map (a). The main strata, groundwater flow paths, recharge, and discharge processes in the catchment were also schematically marked in the map.

Fig. $4 \mathrm{Cl} / \mathrm{Br}$ vs. $\mathrm{Cl}$ (a), $\mathrm{Cl} / \mathrm{Br}$ vs. $\mathrm{Na} / \mathrm{Cl}$ (b) relationships of the analyzed water samples. The blue horizontal line marks the $\mathrm{Sr} / \mathrm{Cl}$ ratio for seawater. The yellow dashed line in Fig. 4b represents the halite dissolution line.

Fig. 5 Relationship between ${ }^{87} \mathrm{Sr} /{ }^{86} \mathrm{Sr}$ vs $\mathrm{Sr}^{2+}(\mathrm{a}) ;{ }^{87} \mathrm{Sr} /{ }^{86} \mathrm{Sr} \mathrm{Vs} \mathrm{Sr} / \mathrm{Cl}(\mathrm{b}) ; \mathrm{Sr}^{2+} \mathrm{Vs} \mathrm{Ca}^{2+}$ (c) from the analyzed samples.

Fig. 6 Relationship between $\delta^{11} \mathrm{~B}$ Vs B (a); B/Cl Vs TDS (b) from the analyzed samples.

Fig. 7 The boron isotopic composition in the analyzed samples. Data from seawater samples (Barth, 1993) and from non-marine evaporates (Vengosh et al., 1994) are also indicated.

Fig. 8 Relationship between $(\mathrm{Ca}+\mathrm{Mg}) \mathrm{Vs} \mathrm{SO}_{4}$ (a); Ca Vs $\mathrm{Mg}(\mathrm{b})$ and $\mathrm{Sr} / \mathrm{Ca} \mathrm{Vs}$. TDS from the analyzed water samples. The dark dashed line in Fig. $8 \mathrm{~b}$ represents the dolomite dissolution line. 


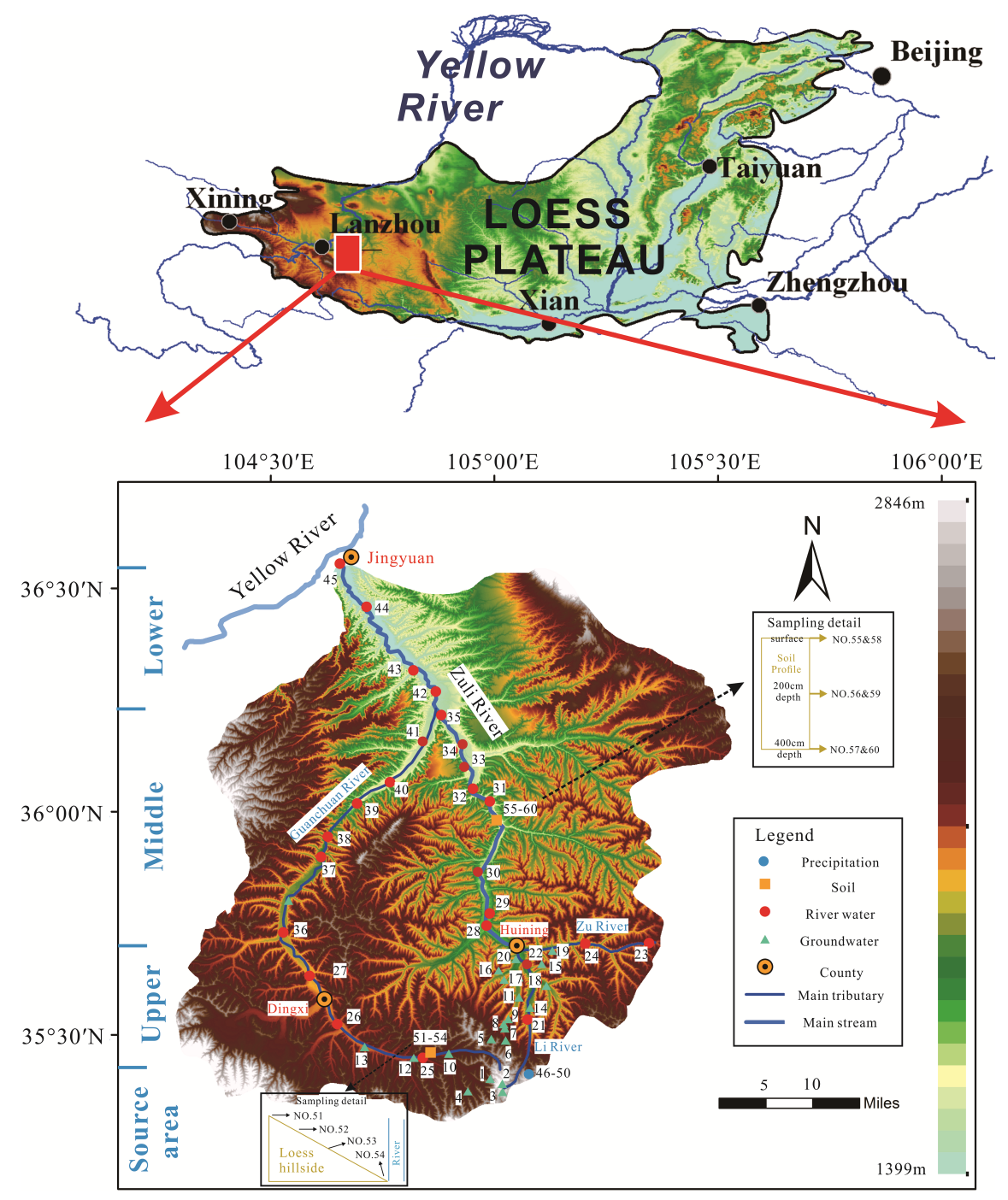



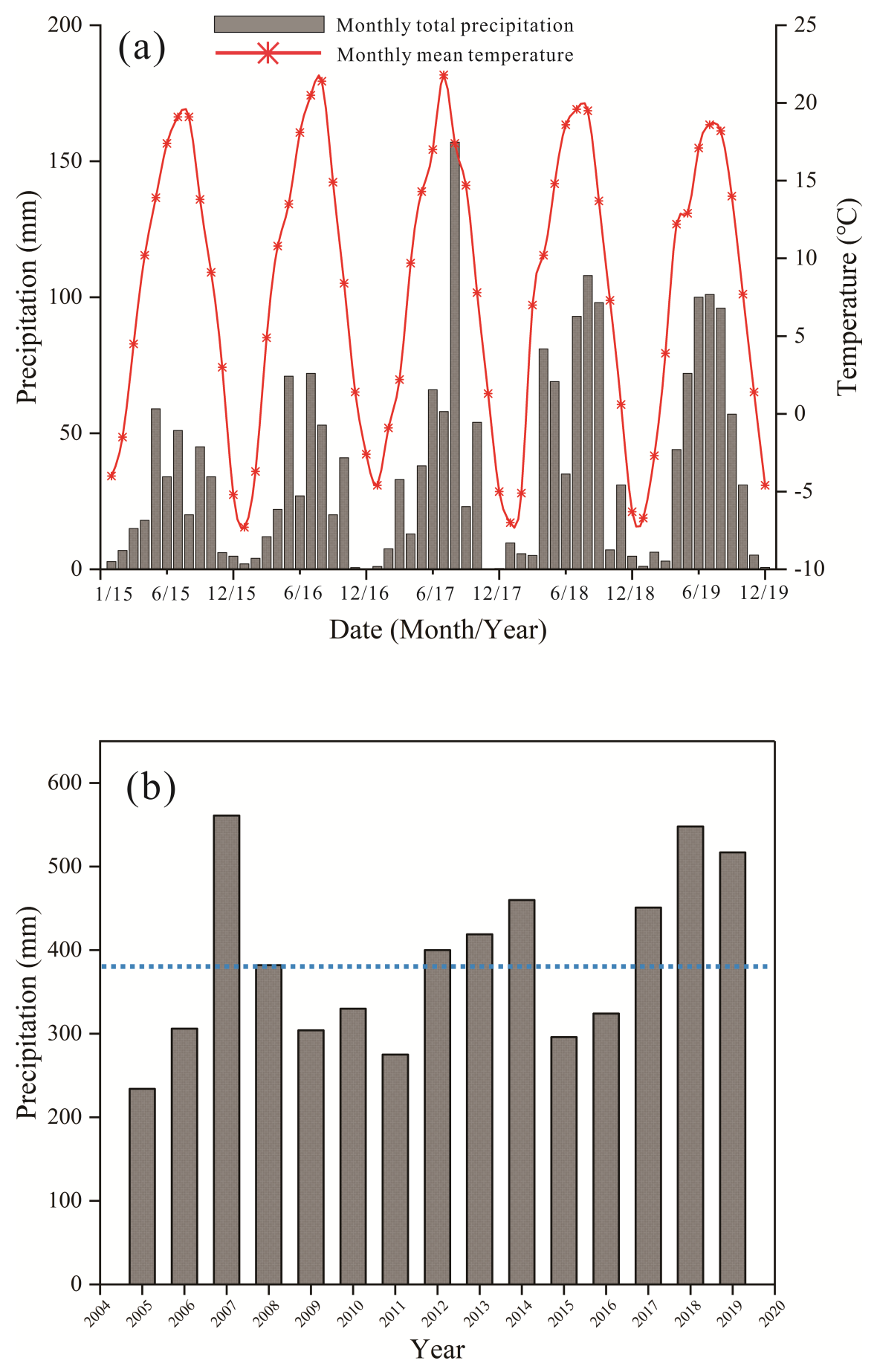

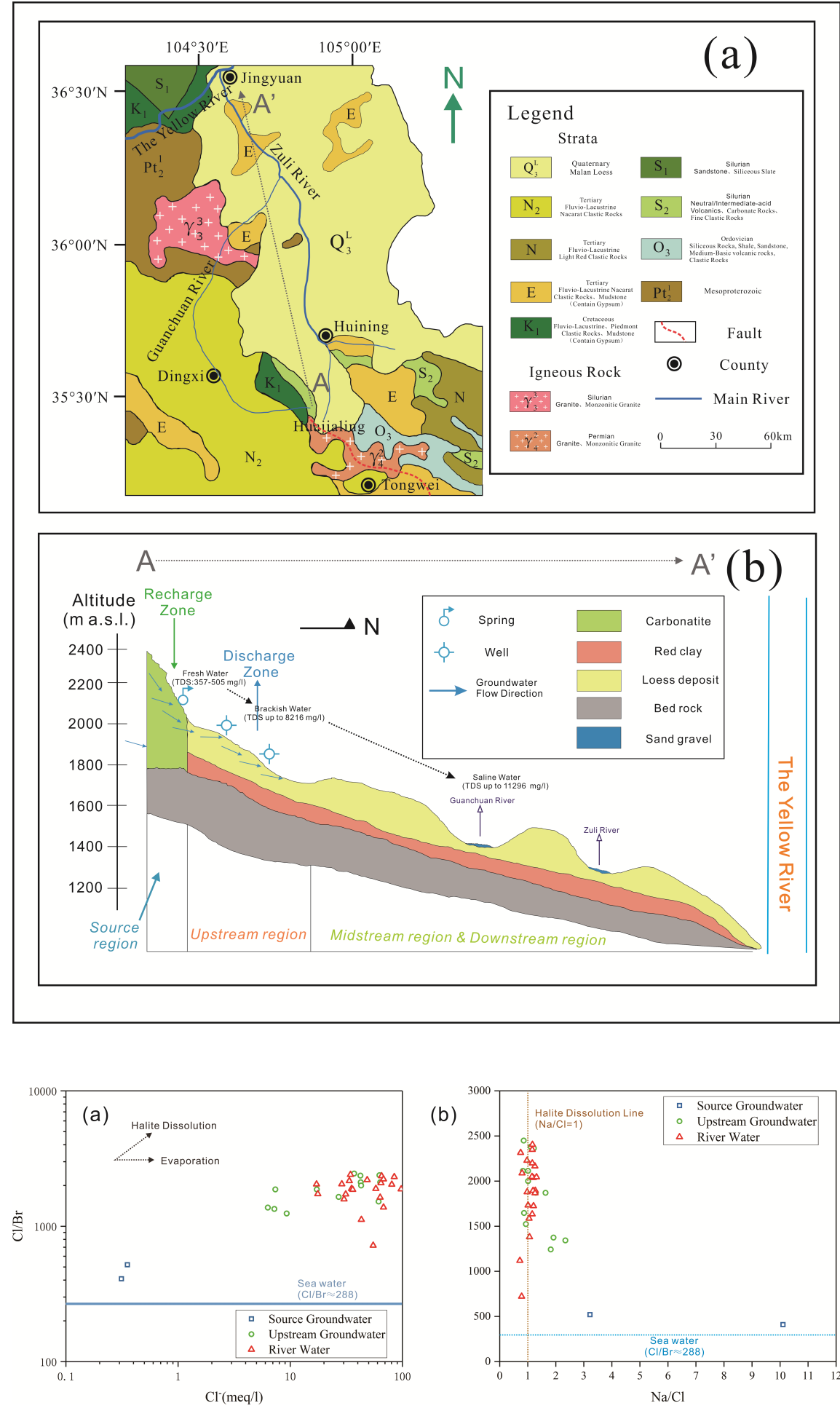

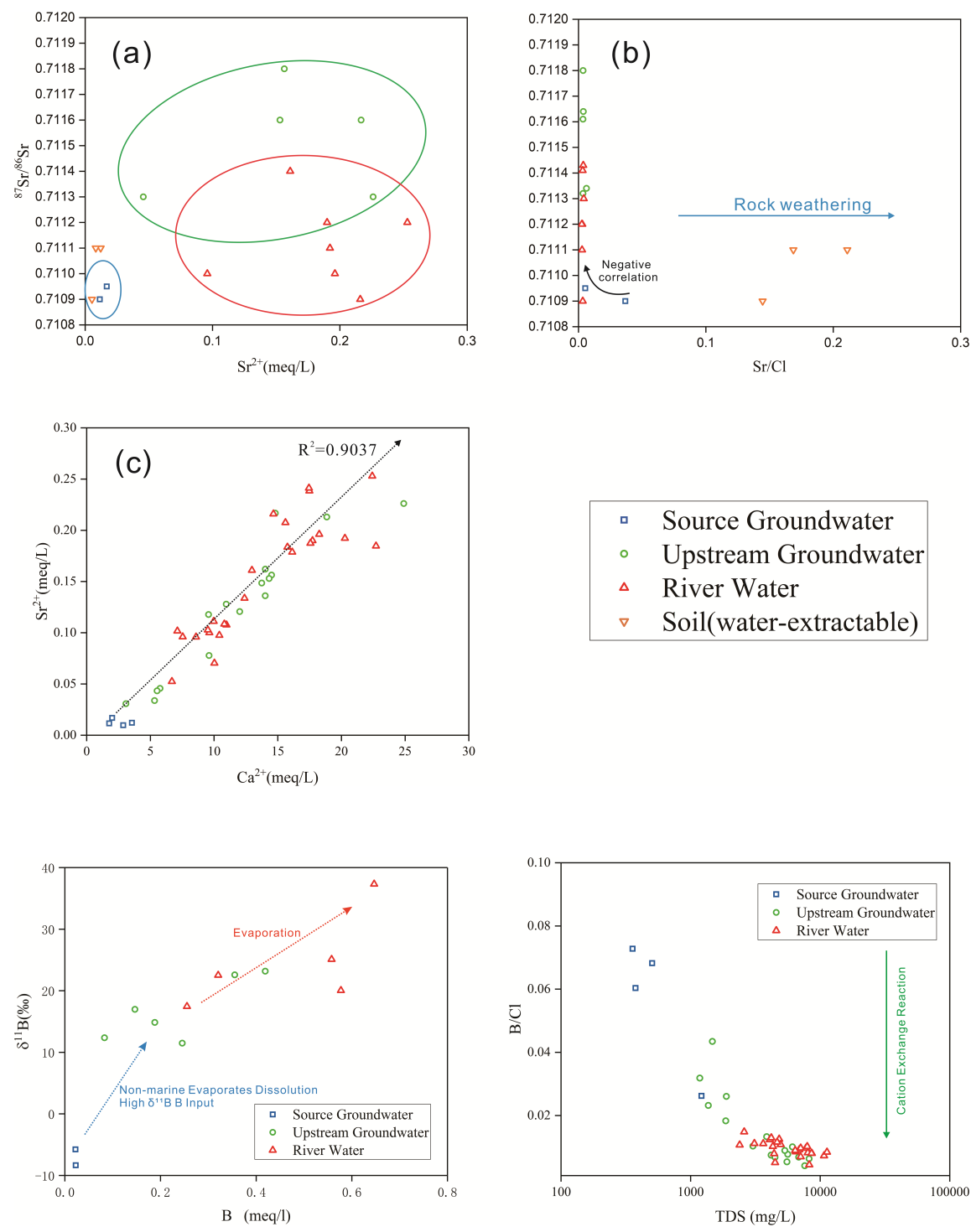


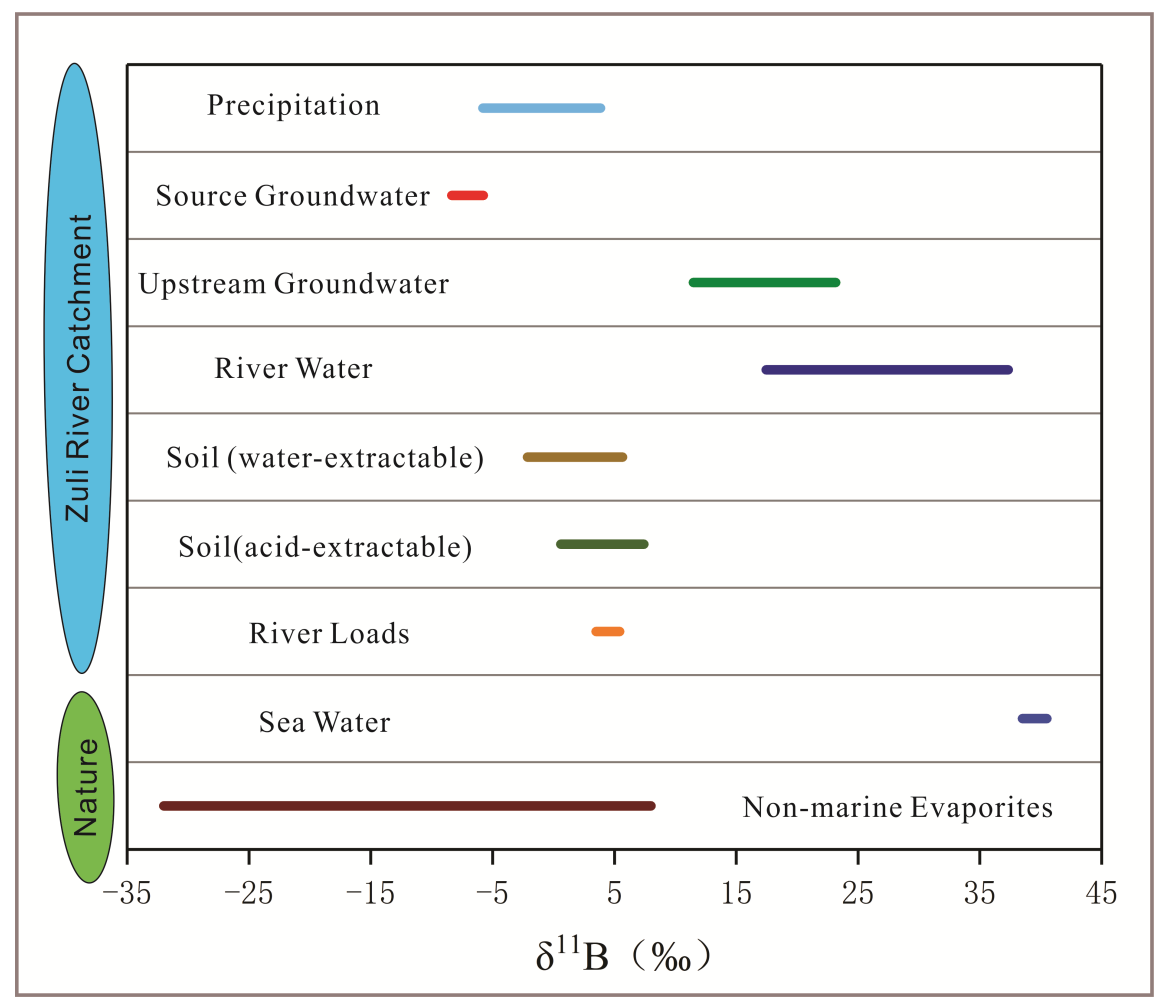
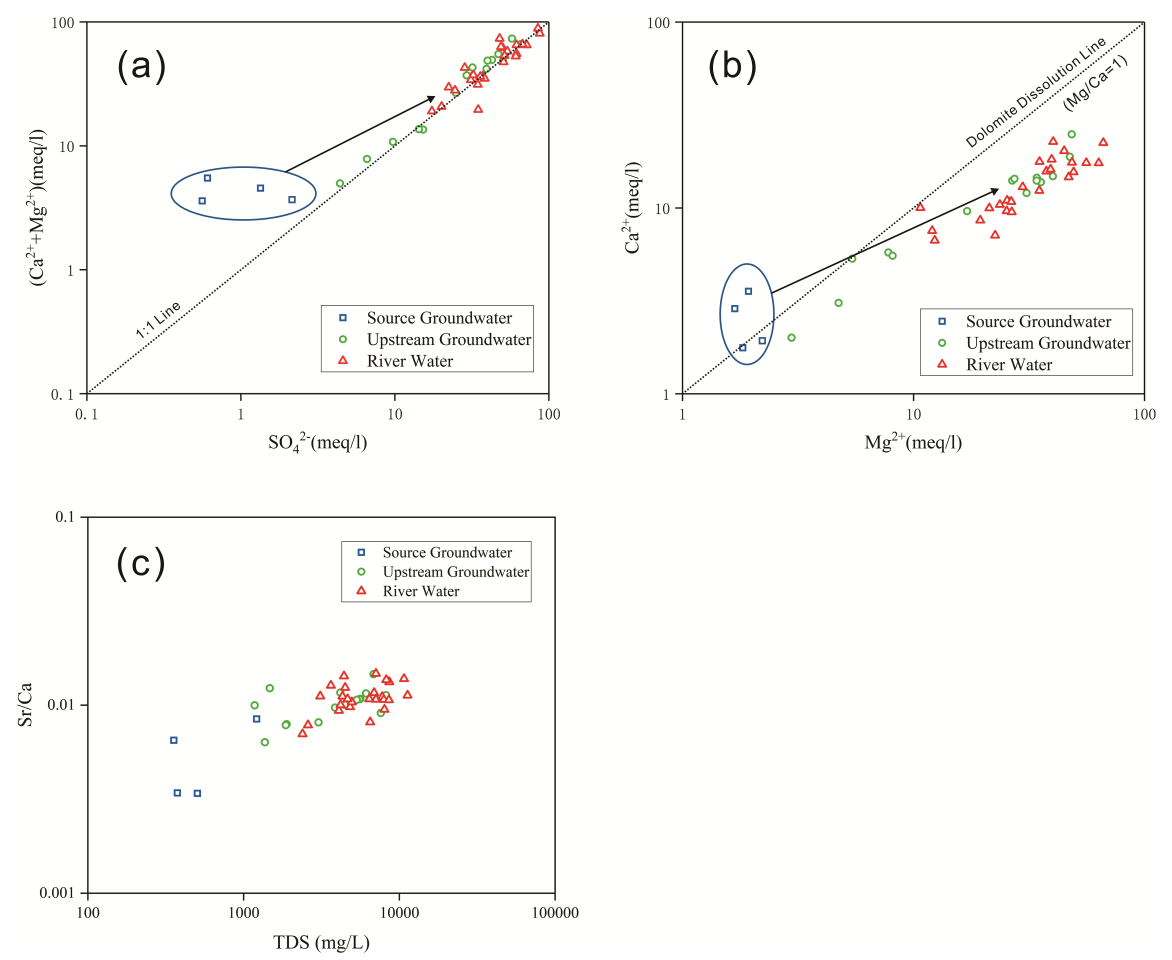

Hosted file 
TABLE.docx available at https://authorea.com/users/338601/articles/465078-significanceof-isotopic-and-geochemical-methods-to-determine-the-evolution-of-inland-brackish-andbitter-water-an-example-from-the-zuli-river-in-the-upper-reaches-of-the-yellow-riverchina 